\title{
ANALISIS KESALAHAN MAHASISWA DALAM MENYELESAIKAN SOAL CERITA BERDASARKAN METODE NEWMANN
}

\author{
Vera Rosalina Bulu \\ Program Studi PGSD, Universitas Citra Bangsa, Jalan Manafe No 17 Kupang, Indonesia \\ E-mail: veraros0451@gmail.com
}

\begin{abstract}
Abstrak
Studi kualitatif ini bertujuan untuk mendeskripsikan kesalahan siswa dalam menyelesaikan soal cerita materi kubus dan balok berdasarkan prosedur newmann. Pengumpulan data diambil dari tiga mahasiswa dari program studi Pendidikan Guru Sekolah Dasar di sebuah Universitas di Kupang - Indonesia, yang terdiri dari mahasiswa dengan kemampuan matematika tinggi, sedang dan rendah dimana hasilnya akan dianalisis lebih lanjut menggunakan metode deskriptif. Hasilnya menunjukkan bahwa siswa dengan kemampuan pemecahan masalah matematika tinggi melakukan kesalahan dalam menulis jawaban akhir karena pemahaman yang tidak lengkap dari kubus dan balok. Mahasiswa dengan kemampuan pemecahan masalah sedang melakukan kesalahan dalam mengubah masalah menjadi simbol matematika karena siswa tidak terbiasa untuk menyelesaikan masalah tidak rutin. Selanjutnya, mahasiswa dengan kemampuan pemecahan masalah rendah melakukan kesalahan dalam mengubah simbol matematika, selama proses dan menulis jawaban akhir. Kesalahan itu muncul karena ketidakmampuan mahasiswa memahami masalah dan pemahaman yang tidak lengkap terhadap konsep kubus dan balok.
\end{abstract}

Kata kunci: Analisis Kesalahan, Metode Newmann, Kubus dan Balok

\begin{abstract}
This Qualitative study aimed to describe the students the mistakes in solving the problems related to cubes and cuboid topics based on Newmann's procedures. To gather the data, three students of primary school teacher department in a university in Kupang, Indonesia, with a high, moderate and low problem - solving skills were chosen to be analyzed further using descriptive method. The result showed that the students with a high problem - solving skill were doing wrong in writing the final answer due to an incomplete understanding of cube and cuboid. The students with a moderate problem - solving skill were doing mistake in transforming the word problems into mathematical expression since the students were not accustomed to do non routine problem. Furthermore, the students with the low problem - solving skills were doing mistakes in transforming word problems into a mathematical expression, during the process and writing the final answer. The mistake was emerged due to students' inability to understand the problems and incomplete understanding of the concept of cube and cuboid.
\end{abstract}

Keywords: Error Analysis, Newmann's method, Cube and Cuboid

\section{PENDAHULUAN}

Matematika merupakan ilmu universal yang mempunyai peranan penting dalam meningkatkan daya pikir manusia dan menghasilkan sumber daya manusia yang berkualitas (Nurfitriyanti, 2016). Selanjutnya, Permendiknas No 21 Tahun 2016 
menjelaskan bahwa pembelajaran matematika diberikan untuk mambantu peserta didik berpikir logis, analitis, sistematis, kritis, kreatif dan bekerjasama. Oleh sebab itu, pemerintah Indonesia memasukan pelajaran matematika dalam kurikulum sekolah, mulai dari jenjang pendidikan dasar sampai pendidikan tinggi.

Berkaitan dengan tujuan pembelajaran tersebut, maka pemecahan masalah merupakan salah satu fokus dalam pembelajaran matematika yang diharapkan dapat membekali peserta didik untuk mengembangkan kemampuan berpikir logis, analitis, sistematis, kritis, kreatif serta kemampuan bekerja sama. Hal ini juga didukung oleh Nurhayati et al. (2016) yang menyatakan bahwa pentingnya kemampuan pemecahan masalah matematika diberikan kepada siswa agar dapat memecahkan masalah matematika dan ilmu pengetahuan lainnya. Lebih lanjut, Bernard et al. (2018) menyatakan bahwa pemecahan masalah dapat membantu peserta didik untuk memproses informasi dan menyusun pengetahuannya mengenai dunia sosial dan sekitarnya.

Masalah matematika adalah situasi dimana persoalan yang mengandung ide-ide matematika, sehingga memberikan potensi untuk tantangan intelektual guna meningkatkan pemahaman dan pengembangan matematika siswa. Masalah matematika biasanya berupa soal-soal yang tidak dapat dengan segera diselesaikan dengan prosedur rutin (Sihombing \& Lintang, 2016). Selanjutnya, Lidinillah (2011) menjelaskan bahwa pemecahan masalah matematika adalah proses menggunakan pengetahuan dan keterampilannya untuk menemukan solusi dari suatu masalah matematika.

Pemecahan masalah matematika dapat dinyatakan dalam bentuk soal tidak rutin yang berupa soal cerita sebab dalam soal cerita bisa menyajikan soal aplikasi terkait pemasalahan dalam kehidupan sehari-hari (Lidinillah, 2011). Hal tersebut didukung oleh pendapat Wahyuddin (2016), yang menyatakan bahwa penyelesaian soal cerita merupakan kegiatan pemecahan masalah sebab dalam soal cerita mengutamakan permasalahan yang berkaitan dengan kehidupan sehari-hari. Sejalan dengan hal tersebut, Nurjanatin et al. (2017) juga menyatakan bahwa pemberian soal cerita dimaksudkan untuk mengenalkan kepada peserta didik tentang manfaat matematika dalam kehidupan sehari-hari dan melatih kemampuan peserta didik dalam menyelesaikan masalah matematika dalam kehidupan sehari-hari. 
Toha et al. (2018) menyatakan bahwa dalam menyelesaikan soal cerita, seseorang dituntut untuk memahami dan menafsirkan soal tersebut dengan keterampilan dan kejelian. Prosedur untuk menyelesaikan soal cerita meliputi membaca dan memahami, membuat model perhitungan serta perhitungan dan menarik kesimpulan. Prosedur tersebut saling terkait dan berkesinambungan. Oleh karena itu jika terdapat kesalahan pada salah satu prosedur maka akan mempengaruhi prosedur berikutnya.

Berdasarkan hasil observasi dan wawancara terhadap dosen dan mahasiswa semester IV Program Studi Pendidikan Guru Sekolah Dasar, Universitas Citra Bangsa ditemukan bahwa kemampuan dalam menyelesaikan soal cerita matematika masih rendah. Hal ini terlihat dari hasil yang didapatkan ketika mengerjakan soal cerita antara lain sekitar 70\% mahasiswa dalam kelas tersebut masih kesulitan mengerjakan soal tersebut jika tidak dibimbing atau tidak dapat mengerjakan soal tersebut, $10 \%$ dapat mengerjakan soal tersebut dengan tepat dan 20\% lainnya dapat mengerjakan soal tersebut dengan sedikit kesalahan. Khususnya pada soal cerita materi bangun ruang kubus dan balok, 80\% mahasiswa menyelesaikan dengan banyak kesalahan.

Kesalahan yang dilakukan oleh mahasiswa perlu untuk dianalisis untuk memudahkan dosen dalam mempertimbangkan solusi untuk mengatasi kesalahan dan penyebab kesalahan mahasiswa tersebut. Sejalan dengan hal tersebut, Amalia (2017) menyatakan bahwa perlu untuk dianalisis kesalahan dalam menyelesaikan soal cerita serta mengapa kesalahan tersebut dapat terjadi. Hal ini dapat memudahkan dosen dan mahasiswa untuk dapat mengidentifikasi kelemahan serta mengambil solusi untuk mengatasi kelemahan tersebut. Selain itu, analisis kesalahan ini dapat bermanfaat bagi mahasiswa sebagai evaluasi diri mengenai kesalahan-kesalahan yang dilakukan dalam menyelesaikan soal cerita dan dapat dicarikan solusi untuk hal tersebut.

Terdapat beberapa metode untuk menganalisis kesalahan dalam menyesaikan soal cerita diantaranya metode Watson dan Newmann. Penelitian ini akan menggunakan metode Newmann untuk memudahkan peneliti dalam menganalisis kesalahan mahasiswa dalam menyelesaikan soal cerita bangun ruang dan kubus berbentuk soal uraian. Junaedi (2012) menjelaskan bahwa prosedur Newmann dirancang sebagai prosedur diagnostik sederhana dalam mengidentifikasi kategori kesalahan terhadap jawaban dari sebuah tes uraian. Selain itu, Jamal (2018) berpendapat bahwa jika dibandingkan dengan metode lain, metode Newmann memiliki tingkat kredibilitas yang paling tinggi. 
Berdasarkan latar belakang di atas, maka tujuan penelitian ini yaitu menganalisis kesalahan mahasiswa dalam menyelesaikan soal cerita bangun ruang kubus dan balok, dengan menggunakan prosedur Newmann. Analisis dilakukan untuk mengetahui penyebab kesalahan mahasiswa dalam menyelesaikan soal cerita bangun ruang kubus dan balok pada mahasiswa semester IV Program Studi PGSD, Universitas Citra Bangsa. Analisis kesalahan tersebut dilakukan pada tiga orang mahasiswa, dengan tiga tingkat kemampuan matematis yang berbeda-beda.

\section{METODE PENELITIAN}

Penelitian ini dilaksanakan pada mahasiswa semester IV, Program Studi Pendidikan Guru Sekolah Dasar, Universitas Citra Bangsa Kupang. Penelitian ini dilaksanakan dengan menggunakan metode penelitian kualitatif deskriptif. Penelitian ini diawali dengan menentukan subjek penelitian. Teknik pemilihan subjek dalam penelitian ini menggunakan purposive sampling yaitu penentuan sampel berdasarkan maksud dan tujuan tertentu.

Berdasarkan tujuan dari penelitian ini, yaitu untuk menganalisis kesalahan dan penyebab dalam menyelesaikan soal cerita bangun ruang kubus dan balok, maka kriteria dalam pemilihan subjek penelitian adalah mahasiswa yang sudah pernah mengikuti mata kuliah matematika khususnya pembelajaran tentang bangun ruang kubus dan balok. Persyaratan lainnya, yaitu subjek dapat berkomunikasi lisan dengan baik, sehingga ketika peneliti melakukan wawancara mendalam, peneliti bisa mendapatkan informasi yang dibutuhkan.

Berdasarkan syarat tersebut dan wawancara dengan dosen matematika, maka terpilih 3 subjek penelitian dari setiap kategori baik kemampuan tinggi, sedang dan rendah serta dapat berkomunikasi dengan baik. Subjek yang terpilih dalam penelitian ini yaitu KF yang merupakan mahasiswa dengan kemampuan matematika tinggi, MK merupakan mahasiswa dengan kemampuan matematika sedang, dan EA, yang merupakan mahasiswa dengan kemampuan matematika rendah. Adapun penentuan kategori kemampuan matematika tinggi, sedang dan rendah berdasarkan nilai akhir Matematika Dasar yang diperoleh dari dosen matematika.

Berikut subjek penelitian berdasarkan kategori kemampuan matematika dapat dilihat pada Tabel 1. 
Tabel 1. Subjek Penelitian Berdasarkan Kemampuan Matematika

\begin{tabular}{lccc}
\hline No & Subjek & $\begin{array}{c}\text { Kemampuan } \\
\text { Matematika }\end{array}$ & Nilai \\
\hline 1 & KF & Tinggi & 78 \\
2 & MK & Sedang & 66 \\
3 & EA & Rendah & 40 \\
\hline
\end{tabular}

Pengumpulan data dilakukan dengan cara memberikan tes dan wawancara kepada subjek penelitian. Oleh sebab itu, instrumen utama yaitu peneliti sendiri dan instrument pendukung berupa soal pemecahan masalah dalam bentuk soal cerita bangun ruang kubus dan balok, pedoman wawancara dan dokumentasi.

Analisis data yang digunakan yaitu analisis data versi Miles dan Huberman. Sugiyono (2013) menyatakan bahwa analisis data kualitatif dilakukan secara interaktif dan berlangsung terus menerus sampai tuntas sehingga datanya jenuh. Prosedur analisis data meliputi reduksi data, penyajian data dan penarikan kesimpulan. Dalam reduksi data peneliti merangkum hal-hal yang pokok, memfokuskan pada hal-hal penting dan membuang hal-hal yang tidak perlu. Dengan demikian data yang telah direduksi akan memberikan gambaran yang lebih jelas dan mempermudah dalam pengumpulan data selanjutnya.

Keabsahan data merupakan langkah selanjutnya untuk mengetahui derajat kepercayaan dari hasil penelitian yang dilakukan dengan menggunakan teknik Triangulasi. Menurut Yenusi, Mumu, dan Tanujaya (2019), triangulasi adalah teknik pemeriksaan data yang memanfaatkan sesuatu yang lain di luar data itu untuk keperluan pengecekan atau pembanding terhadap data itu. Triangulasi dapat dilakukan dalam beberapa aspek, seperti aspek metode, aspek waktu, aspek tempat, aspek sumber data, dan aspek peneliti. Dalam penelitian ini peneliti menggunakan teknik pengumpulan data yang berbeda-beda untuk mendapatkan data dari sumber yang sama. Peneliti menggunakan observasi, wawancara mendalam dan dokumentasi untuk mendukung hasil tes unt uk setiap subyek penelitian.

Analisis kesalahan yang dilakukan mahasiswa berdasarkan pada indikator kesalahan dalam menyelesaikan soal cerita berdasarkan prosedur Newmann yang dapat dilihat pada Tabel 2. 
Tabel 2. Faktor Penyebab dan Indikator Kesalahan Dalam Menyelesaikan Soal Cerita Berdasarkan Prosedur Newmann

\section{Faktor Penyebab}

Kesalahan Siswa

\section{Indikator}

\begin{tabular}{|c|c|c|}
\hline Reading/membaca & a. & $\begin{array}{l}\text { Siswa tidak mampu membaca atau mengenali simbol } \\
\text { atau soal } \\
\text { Siswa tidak mampu memaknai arti setiap kata, istilah } \\
\text { atau simbol dalam soal }\end{array}$ \\
\hline $\begin{array}{l}\text { Comprehension/ } \\
\text { pemahaman }\end{array}$ & a. & $\begin{array}{l}\text { Siswa tidak memahami informasi apa saja yang } \\
\text { diketahui dalam soal dengan lengkap } \\
\text { Siswa tidak memahami apa saja yang ditanyakan } \\
\text { dalam soal dengan lengkap. }\end{array}$ \\
\hline $\begin{array}{l}\text { Transformation/ } \\
\text { transformasi }\end{array}$ & b. & $\begin{array}{l}\text { Siswa tidak mampu membuat model matematis dari } \\
\text { informasi yang didapatkan } \\
\text { Siswa tidak mengetahui rumus yang akan digunakan } \\
\text { untuk menyelesaikan soal } \\
\text { Siswa tidak mengetahui operasi hitung yang akan } \\
\text { digunakan untuk menyelesaikan soal }\end{array}$ \\
\hline $\begin{array}{l}\text { Process Skill/ } \\
\text { keterampilan proses }\end{array}$ & a. & $\begin{array}{l}\text { Siswa tidak mengetahui prosedur yang akan digunakan } \\
\text { untuk menyelesaikan soal dengan tepat. }\end{array}$ \\
\hline $\begin{array}{l}\text { Encoding/penulisan } \\
\text { jawaban akhir }\end{array}$ & b. & $\begin{array}{l}\text { Siswa tidak mampu menemukan hasil akhir dari soal } \\
\text { berdasarkan prosedur yang digunakan. } \\
\text { Siswa tidak dapat menunjukan jawaban akhir dari } \\
\text { penyelesaian soal dengan benar. } \\
\text { Siswa tidak dapat menuliskan jawaban akhir sesuai } \\
\text { dengan kesimpulan. }\end{array}$ \\
\hline
\end{tabular}

\section{HASIL DAN PEMBAHASAN}

Penelitian diawali dengan subyek mengerjakan soal cerita Kubus dan Balok. Hasil perkerjaan subyek penelitian kemudian dianalisis dan dilanjutkan dengan wawancara mendalam terhadap setiap subyek penelitian. Hasil analisis kesalahan untuk setiap tingkat kemampuan matematik dari subyek penelitian disajikan berikut ini. 


\section{a. Subjek Berkemampuan Matematika Tinggi}

Subjek kemampuan tinggi yaitu subjek KF, diminta untuk membaca dan mengerjakan soal cerita kubus dan balok. Hasil jawaban tertulis No 1 dari subjek KF tersaji pada Gambar 1.

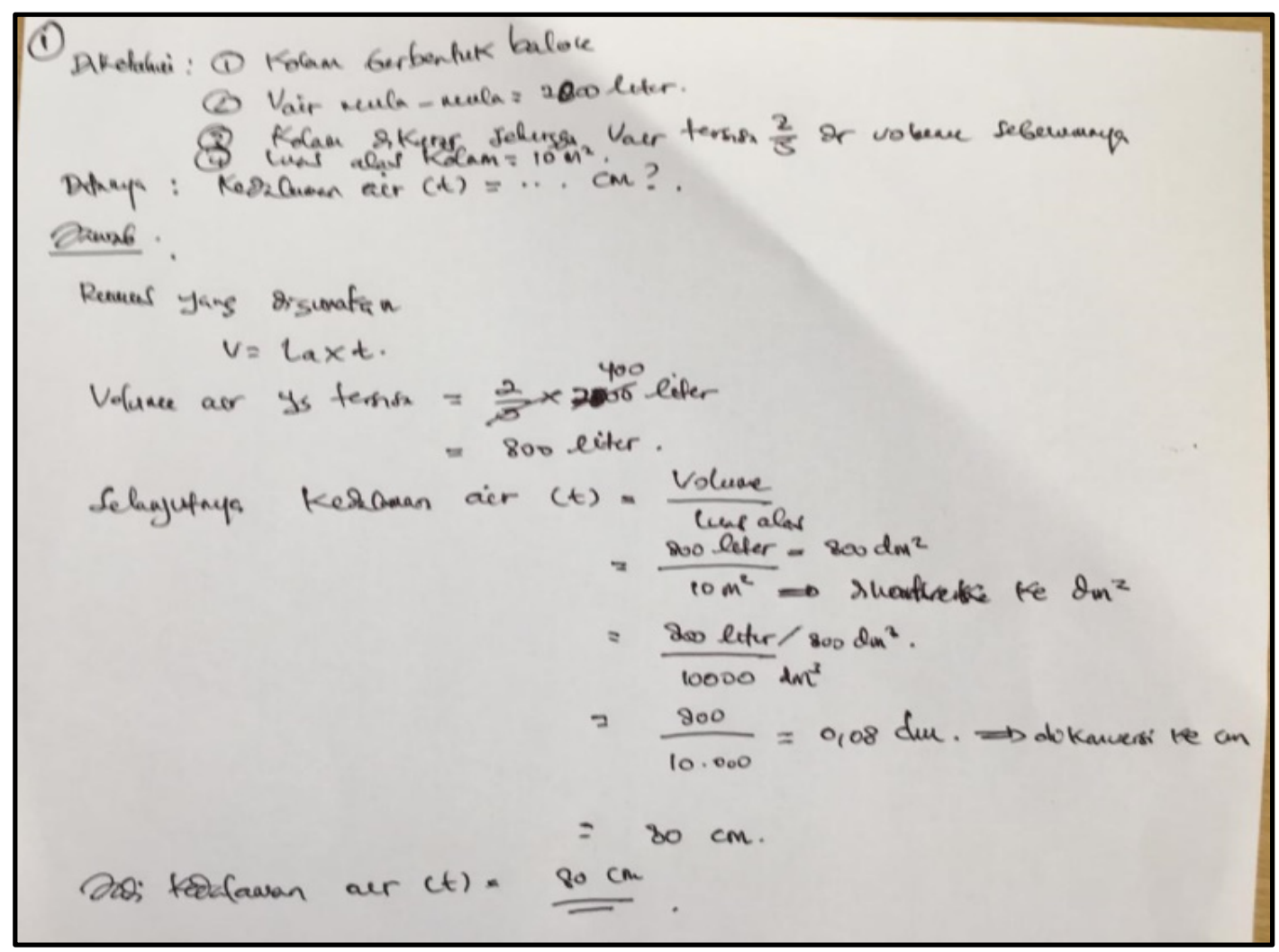

Gambar 1. Jawaban No 1 Subjek KF

Berdasarkan Gambar1., tampak bahwa pada tahap memahami masalah, subjek KF dapat memahami soal tersebut dengan benar. Hal ini terlihat ketika subjek KF mampu menulis apa yang di ketahui dan di tanyakan dengan benar. Simbol-simbol matematika juga dapat di tulis dan di jelaskan dengan benar oleh subyek penelitian. Selanjutnya, berdasarkan hasil wawancara, subjek KF juga dapat menjelaskan informasi yang diketahui dari soal dan hal yang ditanyakan dari soal. Subjek KF dapat menjelaskan kembali maksud soal cerita tersebut dalam bahasa sehari-hari.

Pada Gambar 1., tampak juga bahwa pada tahap merencanakan strategi penyelesaian, subjek KF mampu menuliskan rumus yang digunakan untuk menyelesaikan soal tersebut. Subyek juga mampu melakukan operasi hitung yang digunakan untuk menyelesaikan soal tersebut. Selanjutnya, berdasarkan hasil wawancara subjek KF juga dapat menjelaskan rumus dan operasi hitung yang dipakai 
dalam menyelesaikan soal tersebut.

Lebih lanjut, pada tahap menyelesaikan masalah, subjek KF dapat mengerjakan soal tersebut namun pada langkah terakhir subjek tidak mampu menyelesaikan dengan tepat. Subyek tidak mengetahui cara untuk mengkonversi nilai yang diperoleh dari satuan decimeter $(\mathrm{dm})$ ke satuan centimeter $(\mathrm{cm})$. Selanjutnya, berdasarkan hasil wawancara, subjek KF subjek menjelaskan alasan tidak mengetahui cara mengkonversi dari $\mathrm{dm}$ ke $\mathrm{cm}$, yaitu subjek kurang memahami konsep tentang pengukuran.

Pada tahap terakhir, yaitu pada tahap memeriksa kembali jawaban, subjek KF tidak memeriksa kembali jawaban karena dari awal subjek KF sudah salah mengerjakan. Selanjutnya, pada tahap wawancara subjek tidak mau memeriksa kembali karena sudah yakin jawabannya sejak awal salah.

Berdasarkan triangulasi yang dilakukan yaitu melalui tes dan wawancara dapat disimpulkan bahwa subjek KF yaitu subjek yang mewakili mahasiswa berkemampuan tinggi melakukan kesalahan menyelesaikan soal cerita pada tahap keterampilan proses dan penulisan jawaban akhir. Tiga faktor penyebab kesalahan mahasiswa berkemampuan tinggi diuraikan berikut ini.

1. Kesalahan Keterampilan Proses

Berdasarkan hasil pekerjaan, subjek terlihat mengetahui strategi menyelesaikan soal tersebut. Namun karena kurangnya pemahaman konsep mengenai pengukuran maka pada langkah terakhir subjek tidak dapat menyelesaikan dengan benar. Hal ini sesuai dengan temuan Amalia (2017) yang menyatakan bahwa subjek tidak dapat menyelesaikan soal dengan benar karena kurangnya pemahaman konsep.

\section{Kesalahan Penulisan Jawaban Akhir}

Berdasarkan hasil pekerjaan, terlihat subjek tidak dapat memberikan jawaban terakhir yang benar dan tidak dapat memberikan kesimpulan yang benar. Hal ini karena sejak awal subjek tidak dapat menyelesaikan soal tersebut dengan prosedur yang benar sehingga subjek juga tidak dapat memberikan jawaban dan kesimpulan akhir yang benar.

\section{b. Subjek Berkemampuan Matematik Sedang}

Hasil jawaban tertulis No 1 dari subjek KF dapat dilihat pada Gambar 2, sebagaimana disajikan berikut ini. 


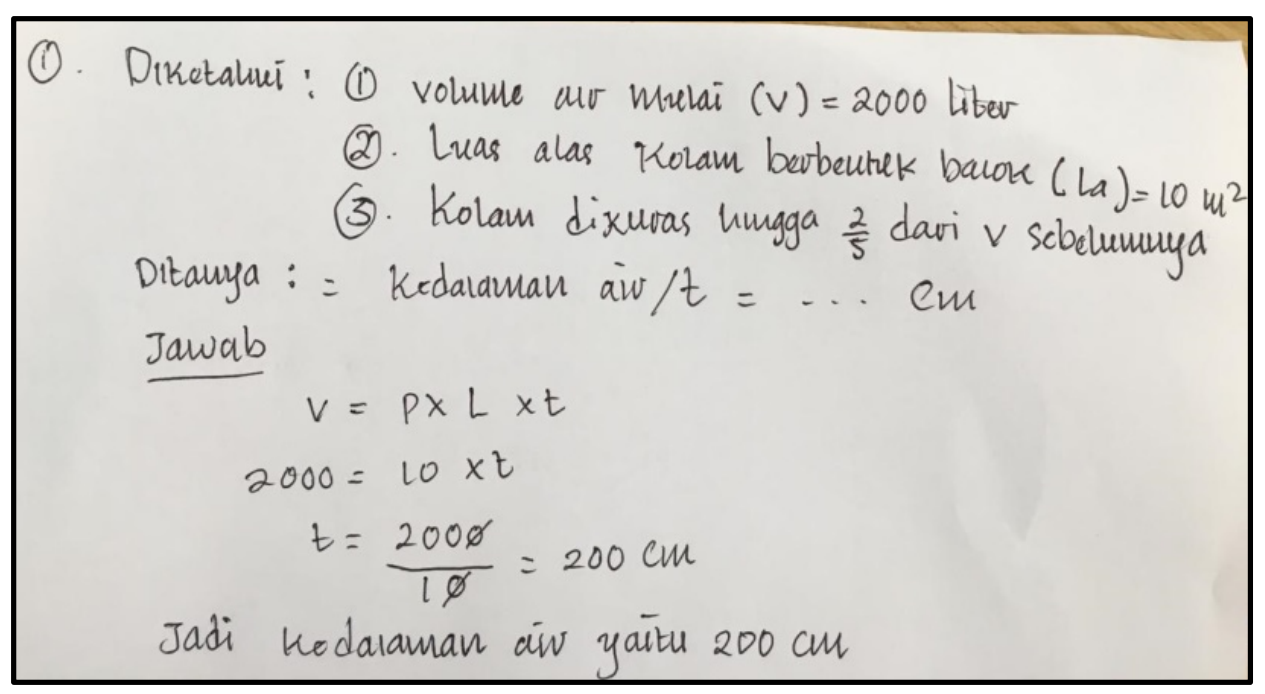

Gambar 2. Jawaban Subjek MK dengan Kemampuan Matematis Sedang

Pada Gambar 2, tampak bahwa pada tahap memahami masalah, subjek MK dapat memahami masalah dengan baik. Hal ini terlihat bahwa subjek mampu menulis informasi yang diketahui dan hal yang ditanyakan dengan benar. Selanjutnya, saat wawancara subjek juga dapat menjelaskan dengan baik informasi yang diketahui dan hal yang ditanyakan dari soal pemecahan masalah tersebut.

Pada tahap merencanakan penyelesaian masalah, subjek MK tidak dapat menulis dengan tepat rumus dan strategi yang digunakan dalam menyelesaikan soal tersebut. Selanjutnya, pada saat wawancara subjek MK juga tidak dapat menjelaskan rumus dan strategi yang dapat dipakai untuk menyelesaikan soal tersebut dengan alasan subjek mk tidak terbiasa berlatih menyelesaikan soal sejenis.

Pada tahap menyelesaikan masalah, subjek MK tidak dapat menyelesaikan soal tersebut dengan prosedur yang benar. Hal ini karena sejak awal subjek MK tidak mengetahui rumus dan strategi yang tepat. Pada saat wawancara, subjek MK juga tidak dapat menjelaskan prosedur yang tepat untuk menyelesaikan soal tersebut serta jawaban yang tepat dari soal tersebut.

Pada tahap memeriksa kembali jawaban, subjek MK tidak memeriksa kembali jawabannya karena sejak awal subjek tidak mengetahui rumus dan strategi yang tepat untuk menyelesaikan soal tersebut. Subjek MK juga tidak dapat memberikan kesimpulan pada penyelesaian soal tersebut.

Berdasarkan triangulasi yang dilakukan yaitu melalui metode tes dan wawancara, dapat disimpulkan bahwa subjek MK melakukan kesalahan menyelesaikan soal cerita pada tahap transformasi, keterampilan proses dan penulisan jawaban akhir. Tiga factor 
penyebab kesalahan mahasiswa berkemampuan matematik sedang, sebagaimaan diuraikan berikut ini.

\section{Kesalahan Transformasi}

Berdasarkan hasil pekerjaan, terlihat subjek MK tidak mengetahui rumus yang digunakan untuk menyelesaikan soal tersebut, walaupun subjek dapat memahami masalah tersebut dengan baik. Hal ini karena subjek tidak terbiasa menyelesaikan soal sejenis sehingga tidak menguasai rumus dan operasi hitung yang berkaitan dengan penyelesaian soal tersebut. Hal tersebut sejalan dengan Amalia (2017) yang menyatakan bahwa walaupun subjek dapat memahami masalah dengan baik, subjek tersebut tidak dapat menyelesaikan masalah dengan baik jika kurang belajar sehingga tidak menguasai materi.

\section{Kesalahan Keterampilan Proses}

Berdasarkan hasil pekerjaan, terlihat subjek MK tidak dapat menyelesaikan soal tersebut menggunakan prosedur yang benar. Seperti halnya penyebab subjek tidak dapat mengetahui rumus, subjek tidak dapat menggunakan prosedur yang benar karena tidak terbiasa menyelesaikan soal sejenis sehingga tidak mengetahui rumus dan operasi hitung yang berkaitan dengan penyelesaian soal tersebut. Temuan tersebut sejalan dengan Saputri, et.al (2018) yang menyatakan bahwa siswa tidak dapat menyelesaikan soal dengan menggunakan prosedur yang benar karena tidak terbiasa menyelesaikan soal sejenis.

\section{Kesalahan Penulisan Jawaban Akhir}

Berdasarkan hasil pekerjaan, terlihat subjek MK tidak dapat memberikan jawaban dan kesimpulan yang benar. Hal ini karena sebelumnya mahasiswa tidak mengetahui rumus dan prosedur yang tepat sehingga subjek juga tidak dapat memberikan jawaban yang benar. Berdasarkan wawancara, subjek tidak terbiasa berlatih soal-soal cerita berkaitan dengan bangun ruang kubus dan balok sehingga tidak mengetahui rumus, prosedur dan jawaban yang tepat.

\section{c. Subjek Berkemampuan Rendah}

Jawaban no 1 dari subjek EA yang mempunyai kemampuan matematis rendah disajikan pada Gambar 3. 


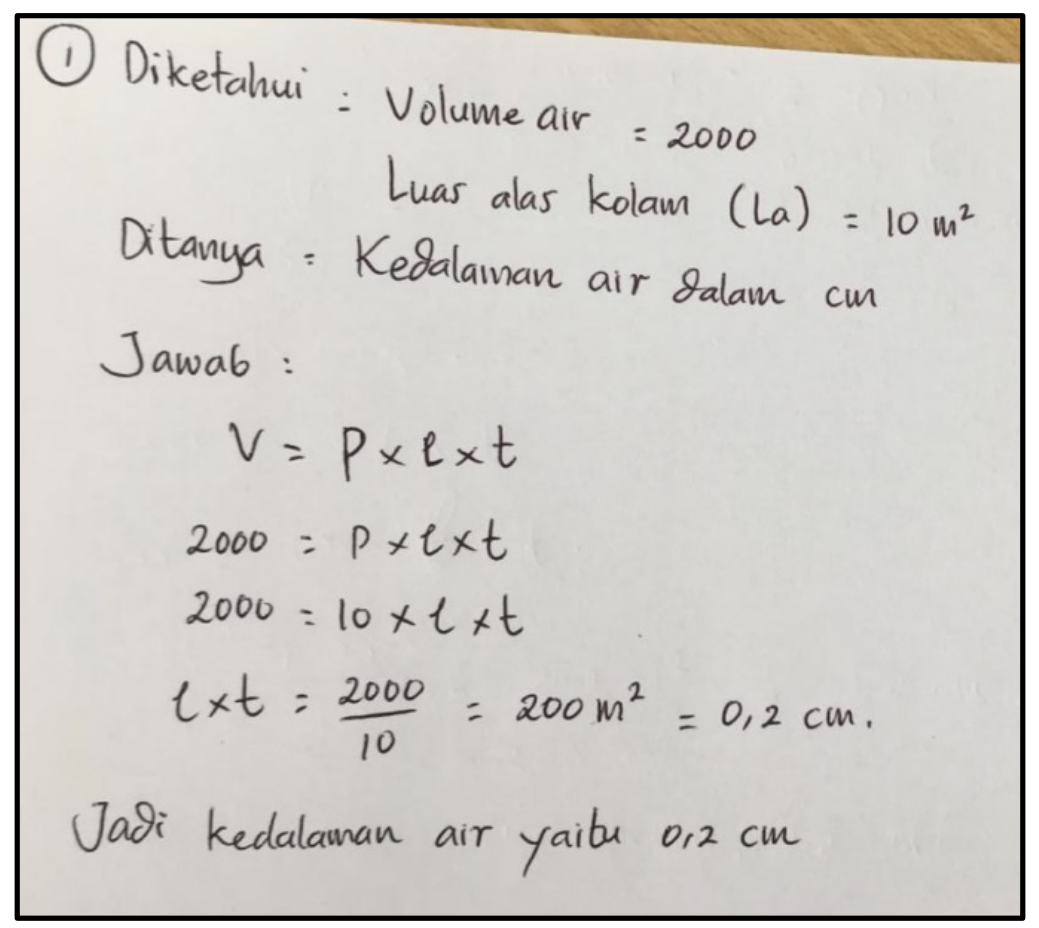

Gambar 3. Jawaban No 1. Subjek EA

Pada Gambar 1, tampak bahwa pada tahap memahami soal, subjek EA tidak dapat memahami soal tersebut dengan benar. Subjek EA tidak mampu menulis informasi yang seharusnya diketahui dan ditanyakan. Pada saat wawancara, subjek EA juga tidak dapat menjelaskan dengan baik informasi yang diketahui dan ditanyakan. Pada waktu mengerjakan soal, subjek EA tergesa-gesa dalam menyelesaikan soal sehingga tidak focus. Selain itu subyek tidak terbiasa berlatih untuk menyelesaikan soal-soal sejenis.

Pada tahap merencanakan penyelesaian masalah, subjek EA tidak mengetahui dengan tepat rumus dan strategi yang dipakai untuk menyelesaikan soal tersebut. Selanjutnya, pada tahap wawancara, subjek juga tidak mengetahui rumus dan strategi dalam menyelesaikan soal tersebut.

Pada tahap menyelesaikan masalah, subjek EA tidak dapat menyelesaikan soal tersebut dengan langkah - langkah yang benar. Hal ini dikarenakan sejak awal subjek EA tidak mengetahui rumus dan strategi yang tepat dalam menyelesaikan soal tersebut.

Pada tahap memeriksa kembali jawaban, subjek EA terlihat tidak memeriksa kembali jawaban yang diberikan karena sejak awal subjek EA tidak yakin dengan strategi dan langkah - langkah yang diberikan. Selanjutnya, subjek EA juga tidak dapat memberikan kesimpulan dari jawaban yang diberikan.

Berdasarkan triangulasi yang dilakukan yaitu melalui metode tes dan wawancara, 
dapat disimpulkan bahwa subjek EA yang mewakili mahasiswa berkemampuan rendah melakukan kesalahan menyelesaikan soal cerita pada tahap membaca, pemahaman, transformasi, keterampilan proses dan penulisan jawaban akhir. Faktor-faktor penyebab kesalahan mahasiswa berkemampuan matematik rendah diuraikan berikut ini.

\section{Kesalahan Membaca}

Berdasarkan hasil pekerjaan, terlihat subjek tidak dapat menulis simbol matematika. Hal ini karena subjek juga tidak terbiasa dengan latihan soal materi bangun ruang. Sehingga tidak terbiasa pula dalam mengenal dan menggunakan simbol-simbol dalam matematika khususnya dalam menyelesaikan bangun ruang kubus dan balok.

\section{Kesalahan Pemahaman}

Berdasarkan hasil pekerjaan, terlihat subjek tidak dapat memahami soal dengan benar selanjutnya ketika di konfirmasi dengan metode wawancara subjek menyatakan bahwa subjek tidak dapat menulis informasi terkait soal karena subjek tidak memahami makna soal tersebut. Adapun penyebabnya yaitu subjek tidak memahami konsep mengenai bangun ruang kubus dan balok ketika dijelaskan oleh dosen, Subjek juga terlalu tergesa - gesa dalam menyelesaikan soal tersebut sehingga tidak fokus dalam menyelesaikan soal tersebut.

Temuan ini sejalan dengan penelitian oleh Juliant dan Noviartati (2016); Ferbriani dan Mukhni (2018), yang menyatakan bahwa subjek sulit untuk memahami soal karena tidak memahami konsep yang berkaitan dengan materi tersebut juga tidak fokus dalam mengerjakan soal tersebut. Lebih lanjut, Saputri, et.al (2018) juga menyatakan hal yang sama bahwa subjek tidak dapat memahami soal dengan baik karena tidak terbiasa berlatih soal yang sejenis.

\section{Kesalahan Transformasi}

Berdasarkan hasil pekerjaan, terlihat subjek tidak menulis strategi yang salah untuk menyelesaikan soal cerita mengenai kubus maupun balok. Selanjutnya ketika dikonfirmasi dalam wawancara, subjek tidak mengetahui strategi yang digunakan untuk menyelesaikan soal cerita karena tidak terbiasa berlatih soal mengenai bangun ruang kubus dan balok serta belum pernah menyelesaikan soal sejenis.

4. Kesalahan Keterampilan Proses

Berdasarkan hasil pekerjaan, terlihat subjek tidak dapat menulis dengan benar, 
langkah - langkah dalam menyelesaikan soal cerita tersebut. Hal ini karena subjek sejak awal tidak mengetahui strategi yang digunakan sehingga berpengaruh subjek juga tidak mengetahui prosedur yang digunakan untuk menyelesaikan soal cerita tersebut.

\section{Kesalahan Penulisan Jawaban Akhir}

Berdasarkan hasil pekerjaan, terlihat subjek tidak dapat memberikan jawaban yang benar serta kesimpulan yang benar mengenai jawaban soal cerita tersebut.

Selanjutnya, kaitannya dengan kesalahan mahasiswa dalam menyelesaikan soal cerita berdasarkan kemampuan matematis, temuan yang didapatkan yaitu Mahasiswa dengan kemampuan matematis yang berbeda, melakukan kesalahan yang berbeda pula dalam menyelesaikan soal cerita bangun ruang kubus. Hal ini sejalan dengan temuan Juliant dan Noviartati (2016) dalam penelitiannya mengenai analisis kesalahan siswa dalam menyelesaikan soal cerita pola bilangan ditinjau dari kemampuan matematika siswa. Hasil penelitiannya menunjukan bahwa siswa berkemampuan tinggi, sedang dan rendah melakukan kesalahan yang berbeda beda dalam menyelesaikan soal cerita mengenai pola bilangan. Selanjutnya, ditemukan bahwa semakin rendah kemampuan matematika yang dimiliki maka semakin banyak pula kesalahan yang dilakukan.

Berkaitan dengan penyebab dalam melakukan kesalahan menurut Juliant dan Noviartati antara lain disebabkan karena siswa tidak memahami konsep dan kurang berlatih soal - soal yang berkaitan dengan materi pola bilangan. Temuan ini sesuai dengan penyebab yang ditemukan dalam penelitian ini yaitu kesalahan yang dibuat diantaranya karena siswa tidak memahami konsep dan kurang berlatih soal - soal yang berkaitan dengan materi tersebut.

Ardiyanti (2014); Yolandia (2017) juga menemukan bahwa siswa yang memiliki kemampuan yang berbeda akan melakukan kesalahan yang berbeda pula. Berdasarkan uraian penelitiannya diperoleh bahwa semakin rendah kemampuan matematikanya maka semakin banyak pula kesalahan yang dilakukan. Selanjutnya, Yolanda (2017); Sari dan Aripin (2018); Saputri, et.al (2018); Ferbriani dan Mukhni (2018) juga menemukan bahwa penyebab siswa melakukan kesalahan daintaranya karena siswa tidak memahami konsep dan kurang berlatih soal - soal latihan yang berkaitan dengan materi tersebut. 


\section{SIMPULAN}

Kesalahan mahasiswa dalam menyelesaikan soal cerita materi Bangun Ruang Kubus dan Balok berhubungan dengan kemampuan matematika mahasiswa. Mahasiswa dengan kemampuan matemnatika yang tinggi cenderung melakukan kesalahan yang lebih sedikit dibandingkan jumlah kesalahan yang dilakukan mahasiswa dengan kemampuan matematika yang rendah. Mahasiswa berkemampuan matematiki tinggi, melakukan kesalahan keterampilan proses dan penulisan jawaban akhir, mahasiswa berkemampuan matematika sedang melakukan kesalahan transformasi, keterampilan proses dan penulisan jawaban akhir, sedangkan mahasiswa berkemampuan matenmatika rendah melakukan kesalahan membaca, pemahaman, transformasi, keterampilan proses dan penulisan jawaban akhir.

\section{DAFTAR RUJUKAN}

Amalia, S. R. (2017). Analisis Kesalahan Berdasarkan Prosedur Newmann Dalam Menyelesaikan Soal Cerita Ditinjau Dari Gaya Kognitif Mahasiswa. Aksioma, $8(1), 17-30$.

Ardityanti, Bharata, H., Yunarti, T. (2014). Analisis Kesalahan Siswa Dalam Menyelesaikan Soal Cerita. Jurnal Pendidikan Matematika Universitas Lampung. 2(7), 1-9.

Bernard, M., Nurmala, N., Mariam, S., \& Rustyani, N. (2018). Analisis Kemampuan Pemecahan Masalah Matematis Siswa SMP Kelas IX Pada Materi Bangun Datar. Supremum Journal of Mathematics Education, 2(2), 77-83.

Febriani, D. E., \& Mukhni. (2018). Analisis Kesalahan Siswa dalam Menyelesaikan Soal Cerita Matematika Berdasarkan Analisis Kesalahan Newmanpada Siswa Kelas VIII SMP Negeri 7 Padang. Jurnal Edukasi dan Penelitian Matematika, 7(4), 24-29.

Jamal, F. (2018). Analisis Kesalahan Dalam Menyelesaikan Soal Cerita Pertidaksamaan Kuadrat Berdasarkan Prosedur Newmann. Jurnal Maju, 5(2), 41-51.

Juliant, A., \& Noviartati, K., (2016). Analisis Kesalahan Siswa dalam Menyelesaikan Soal Pada Materi Pola Bilangan Ditinjau dari Kemampuan Matematika Siswa. Jurnal Riset Pendidikan, 2(2), 111-118.

Junaedi, I. (2012). Tipe Kesalahan Siswa dalam Menyelesaikan Soal-Soal Geometri 
Analitik Berdasar Newmann's Error Analysis (NEA). Jurnal Kreano, 3(2), 125133.

Kemdikbud (2016). Permendikbud No 21 Tahun 2016 tentang Standar Isi. Jakarta: Kemdikbud

Lindinillah, D.A.M. (2011). Heuristik Dalam Pemecahan Masalah Matematika Dan Pembelajarannya Di Sekolah Dasar. Jurnal Elektronik Universitas Pendidikan Indonesia.

Nurfitriyanti, M. (2016). Model Pembelajaran Project Based Learning terhadap Kemampuan Pemecahan Masalah Matematika. Formatif: Jurnal Ilmiah Pendidikan MIPA, 6(2), 149-160.

Nurhayati, E. (2016). Penerapan Scafolding untuk Pencapaian Kemampuan Pemecahan Masalah Matematis. Jurnal Penelitian Pendidikan dan Pengajaran Matematika, 2(2), 107-112.

Nurjanatin, I., Sugondo, G., \& Manurung, M.M.H. (2017). Analisis Kesalahan Peserta Didik dalam Menyelesaikan Soal Cerita pada Materi Luas Permukaan Balok di Kelas VIII -F Semester II, SMP Negeri 2 Jayapura. Jurnal Ilmiah Matematika dan Pembelajarannya, 2(1), 22-31.

Saputri, R.R., Sugiarti, T., Murtikusuma, R.P., Trapsilasiwi, D., \& Yudianto, E. (2018). Analisis Kesalahan dalam Menyelesaikan Materi Fungsi Berdasarkan Kriteria Watson Ditinjau Dari Perbedaan Gender Siswa SMP Kelas VIII. Kadikma, 9(2), 59-68.

Sari, R. A., \& Aripin, U. (2018). Analisis Kesalahan Siswa dalam Menyelesaikan Soal Cerita Bangun Datar Segiempat Ditinjau Dari Kemampuan Pemecahan Masalah Matematik Untuk Siswa Kelas VII. Jurnal Pembelajaran Matematika Inovatif, 1(6), 1135-1142.

Sihombing, M.K.S., \& Lintang, S. (2016). Kemampuan Siswa Dalam Menyelesaikan Masalah Matematika Menggunakan Strategi Pengambilan Sudut Pandang Yang Berbeda. Prosiding Seminar Nasional Reforming Pedagogy, Yogyakarta: Universitas Sanata Dharma.

Sugiyono. (2013). Metode Penelitian Kuantitatif, Kualitatif dan R\&D. Bandung: Alfabeta.

Suyitno, A., (2015). Learning Therapy For Students In Mathematics Communication 
Correctly Based On Application Of Newmann Procedure. International Journal of Education and Research, 3(1), 1-10.

Toha, M., Mirza, A., Ahmad, D. (2018). Analisis Kesalahan Siswa Dalam Menyelesaikan Soal Cerita Materi Perbandingan Kelas VII SMP. Pendidikan Matematika, FKIP, Universitas Tanjungpura. 1-10.

Wahyuddin. (2016). Analisis Kemampuan Menyelesaikan Soal Cerita Matematika Ditinjau Dari Kemampuan Verbal, Jurnal Tadris Matematika, 9(2), 148-160.

Yenusi, T., Mumu, J., \& Tanujaya, B., (2019). Analisis Sial Latihan pada Buku Paket SMA yang Bersesuaian dengan Higher Order Thinking Skill, Journal of Honai Math, 2(1), 53-64.

Yolandia, Y. (2017). Analisis Kesalahan Siswa dalam Menyelesaikan Soal Cerita Berdasarkan Newmanns Error Analysis (NEA) Ditinjau dari Kemampuan Awal Matematisnya Pada Materi Lingkaran. Pendidikan Matematika FKIP, Universitas Jambi (pp. 1-13). 